\title{
LONG-TERM AIR POLLUTION TREND ANALYSIS IN MALAYSIA
}

\author{
JUSTIN SENTIAN, FRANKY HERMAN, CHAN YIT YIH AND JACKSON CHANG HIAN WUI \\ Faculty of Science and Natural Resources, University Malaysia Sabah, Malaysia
}

\begin{abstract}
Air pollution has become increasingly significant in the last few decades as a major potential risk to public health in Malaysia due to rapid economic development, coupled with seasonal trans-boundary pollution. Over the years, air pollution in Malaysia has been characterised by large seasonal variations, which are significantly attributed to trans-boundary pollution. The aim of this study is to analyse the long-term temporal dynamic (1997-2015) of $\mathrm{CO}, \mathrm{NO}_{\mathrm{x}}$ and $\mathrm{PM}_{10}$ at 20 monitoring stations across Malaysia. Long-term pollutant trends were analysed using the Mann-Kendall test. For potential pollutant source analysis, satellite data and Hybrid Single-Particle Lagrangian Integrated Trajectory (HYSPLIT) backward trajectories model were employed. In all monitoring sites, we observed that the annual average concentrations of $\mathrm{PM}_{10}$ were varied, with large coefficient variations. Meanwhile, $\mathrm{CO}$ and NOx were found to be less varied, with smaller coefficient variations, except in certain monitoring sites. Long-term analysis trends for $\mathrm{CO}$ attested to insignificant decreasing trends in 11 monitoring stations and increasing trends in seven stations. Meanwhile, $\mathrm{NO}_{\mathrm{x}}$ showed no significant trends in most stations. For $\mathrm{PM}_{10}$, five monitoring stations showed increasing trends, whereas 15 other stations showed decreasing trends. HYSPLIT backward trajectory analyses have shown that high seasonal $\mathrm{PM}_{10}$ levels in most parts of Malaysia are due to trans-boundary pollution. Large-scale intense biomass burning in Indonesia, particularly during the southwest monsoon, has been identified as the main potential source. Long-term air pollution in Malaysia is characterised largely by trans-boundary pollution and is highly seasonal. In urban areas of Malaysian Peninsula, combinations of trans-boundary pollution and local emission sources were notably identified as important sources. Long-term $\mathrm{PM}_{10}$ pollution in Malaysia shows small but significant decreasing trends. Therefore, to ensure that the effect of air pollution on human health is minimised, special attention needs to be focused on short-term pollution episodes, particularly during trans-boundary pollution events and extreme weather conditions such as El Niño. Keywords: air pollutants, El-Niño, HYSPLIT, biomass burning, trans-boundary pollution.
\end{abstract}

\section{INTRODUCTION}

Air pollution is broadly understood as any material of any source within the atmosphere, which exists in either solid, liquid or gas phase that has destructive effects or the ability to modify the natural characteristics of the atmosphere and poses a health risk to living things, or which causes the deterioration of the environment and ecosystem [1,2]. Typically, pollutants come from both natural sources (i.e. plant pollens, wind-blown dust, volcanic emissions and lightning-induced forest fires) and anthropogenic sources (i.e. transportation emissions, industrial emissions and emissions from other processing activities) [3-5]. Common air pollutants include particulate matters (particularly $\mathrm{PM}_{10}$ and $\left.\mathrm{PM}_{2.5}\right)$, carbon monoxide $(\mathrm{CO})$, ozone $\left(\mathrm{O}_{3}\right)$, sulphur $(\mathrm{S})$, sulphur dioxide $\left(\mathrm{SO}_{2}\right)$ and nitrogen oxides $\left(\mathrm{NO}_{\mathrm{x}}\right)$, acid gases, heavy metals, volatile organic compounds (VOCs), solvents, pesticides, radiation and bio-aerosols [6,7].

On the basis of available scientific studies, short- and long-term exposure to air pollutants poses different toxicological impacts on living things [7]. Eye irritation, skin disease, nausea and cardiovascular infection have been affirmed as associated short-term effects of poor air quality [8]. In addition, several studies have linked the long-term effects of air quality exposure to lung inflammation and cardiovascular disease, fatal heart diseases [9-12] asthma $[9,11,13,4]$, the carcinogenic effects of lung cancer [11,15-17], neuropsychiatric complications $[15,18,19]$, ventricular hypertrophy [20,21] and Alzheimer [15,22], neurological 
disorder [22,23], innate immune system [22] and Parkinson's syndrome [22]. Hence, available scientific studies have proven that many of the diseases linked to distortion of immune system and risks of morbidity and mortality are associated with low air quality. High genotoxic potential has been associated with exposure of fine and coarse aerosol particles that reach the alveolar region of the lungs [24]. In Malaysia, respiratory mortality and natural mortality have been found to be significantly associated with daily mean of $\mathrm{O}_{3}, \mathrm{CO}, \mathrm{NO}_{2}$ and $\mathrm{PM}_{10}[25,26]$. The highest relative risk (RR) in the single-pollutant model was observed for $\mathrm{PM}_{10}$ and $\mathrm{O}_{3}$, indicating that an increase in $\mathrm{PM}_{10}$ exposure was associated with a maximum increase of $0.99 \%$ in natural mortality and a $3.63 \%$ increase in respiratory mortality [26].

Malaysia ranked as the third highest country for pollutant emissions in Southeast Asia after Indonesia and Thailand [27]. For the past decades, the major sources of air pollution in Malaysia are power plants (85\%), motor vehicles (10\%), industrial activity (3\%) and other sources (2\%) [28]. The increase of demand for motor vehicles between 1996 and 2015 and rapid industrialisation, especially in the western corridor of the Malaysian Peninsula, has caused the increase of air pollutant emissions, thus inevitably affecting local and regional air quality $[25,27,29]$. Until the 1980s, air pollution was generally regarded as a local issue and confined to nearby emission sources or urban areas, but now several air pollution issues have been reported and become a regional issue as pollutants are transported over long distances and have adverse effects on the environment on a wider scale [30].

The rising trend of trans-boundary air pollution and episodic haze and their associated health impacts is becoming a greater concern in Malaysia [26,30-32]. Seasonally, open biomass burning in neighbouring regions, particularly Indonesia and Indochina, have been known to contribute to the air quality deterioration in Malaysia [29-33]. Severe haze episodes in Malaysia due to trans-boundary pollution, originated largely from Indonesia, were recorded in April 1983, August 1990, June 1991, October 1991, August 1994 and September 1997 [32]. The episode in 1997 was singled out as the worst in Malaysian air quality records by reaching the hazardous level of air pollution index (API) [29,32]. Haze episodes in September to November 2015, also due to trans-boundary pollution from Indonesia, caused low air quality in Malaysia [34], where 34 over 52 air quality monitoring stations recorded API levels of exceeding 200. This is considered the worst haze episode in recent decades [35].

In Malaysia, the southwest monsoon wind and trans-boundary pollution have greatly influenced national air quality $[30,31,34,36]$. The geographic location of Malaysia, which lies in
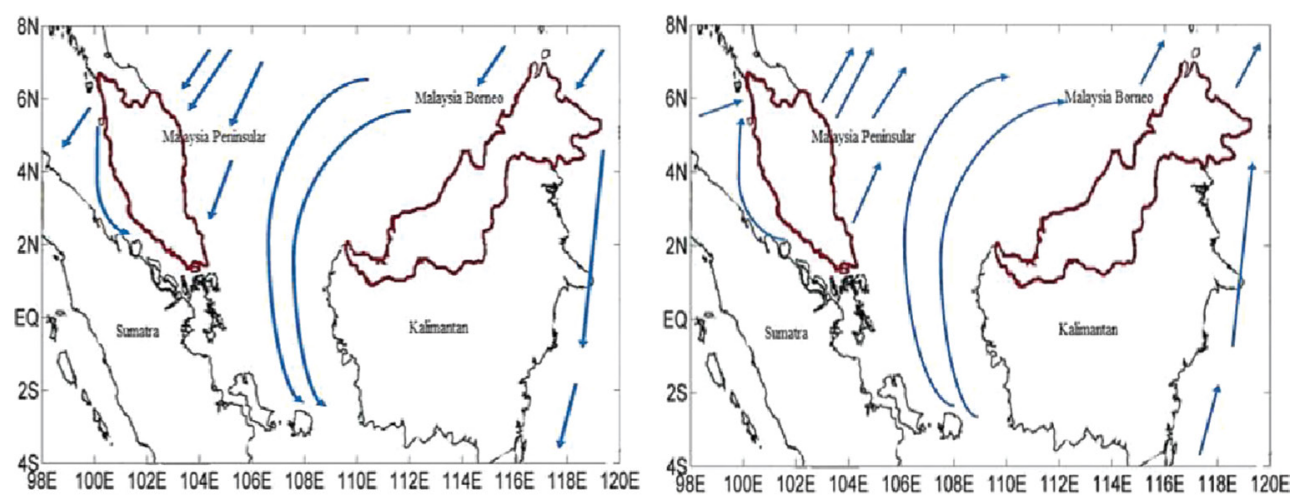

Figure 1: Conceptual model of prevailing wind flow (blue arrows) during NE monsoon (left panel) and SW monsoon season (right panel). 
the main pathway of the Southeast Asian pollution outflow (Fig. 1), has caused significant exposure to regional aerosol and pollutant emissions [34,36]. The southern and central areas of the Malaysian Peninsula have been the worst area affected by the trans-boundary haze originating from Sumatra, Indonesia, due to large and intense burning of peat soil and plant residues in releasing high concentrations of particulate matter [34,37]. In urban areas of the Malaysian Peninsula during normal periods, the air quality is characterised by local emissions, mostly emissions from traffic, industries as well as local biomass burning [25,29]. In understanding the air pollution dynamic, this paper is aiming to characterise the long-term temporal dynamic and variations of $\mathrm{CO}, \mathrm{NO}_{\mathrm{x}}$ and $\mathrm{PM}_{10}$ in Malaysia. In supporting this aim and to enhance regional understanding on air pollution variations and its potential sources, assessment of the regional long-term pollution trend and its link with seasonal trans-boundary pollution episodes and El Niño events will be explored.

\section{METHODOLOGY}

\subsection{Site description}

The air quality pollutants considered in this study are $\mathrm{CO}, \mathrm{NO}_{\mathrm{x}}$ and $\mathrm{PM}_{10}$, with data obtained from 20 air quality monitoring stations of a total of 61 monitoring stations in Malaysia. The selection of the 20 monitoring sites is due to the availability of long-term air quality data for all selected pollutants. The selections of the 20 monitoring station are based on regional representation (northern, central, southern and eastern Malaysian Peninsula and Malaysian Borneo) as well as the surrounding land use setting (urban, sub-urban, industrial and rural) as shown in Fig. 2 and Table 1.

\subsection{Climatic variations and air quality datasets}

Malaysia has a typical tropical climate governed by the regional wind systems, which result from the atmospheric pressure distribution over the region. The seasonal fluctuation of the inter-tropical convergence zone (ITCZ) and the associated trade wind fields in the region

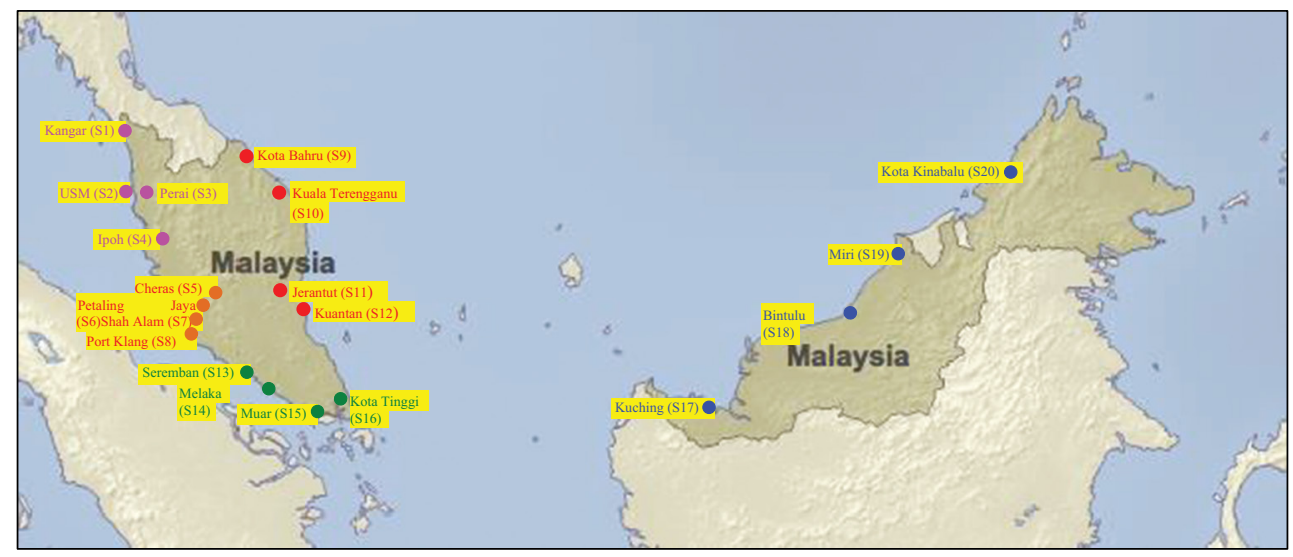

Figure 2: Selected locations of air quality monitoring stations (S1-S20) for the investigation of long-term air quality analysis in Malaysia. 
Table 1: Selected 20 air quality monitoring stations (S1-S20) in different regions and site characteristics.

\begin{tabular}{|c|c|c|c|}
\hline Region & Area status & Location (station) & Coordinate (Lat, Long) \\
\hline \multirow{4}{*}{$\begin{array}{l}\text { Northern Peninsular } \\
\text { Malaysia }\end{array}$} & Suburban & Kangar (S1) & $6.25,100.11$ \\
\hline & Suburban & USM (S2) & $5.21,100.17$ \\
\hline & Industrial & Perai (S3) & $5.23,100.24$ \\
\hline & Urban & Ipoh (S4) & $4.33,101,04$ \\
\hline \multirow{4}{*}{$\begin{array}{l}\text { Central Peninsular } \\
\text { Malaysia }\end{array}$} & Urban & Cheras (S5) & $3.06,101,40$ \\
\hline & Industrial & Petaling Jaya (S6) & $3.06,101.42$ \\
\hline & Urban & Shah Alam (S7) & $3.06,101.33$ \\
\hline & Urban & Port Klang (S8) & $3.00,101.24$ \\
\hline \multirow{4}{*}{$\begin{array}{l}\text { Eastern Peninsular } \\
\text { Malaysia }\end{array}$} & Urban & Kota Bahru (S9) & $6.09,102.15$ \\
\hline & Urban & Kuala Terengganu (S10) & $5.18,103.07$ \\
\hline & Suburban & Jerantut (S11) & $3.58,102.20$ \\
\hline & Suburban & Kuantan (S12) & $3.49,103.17$ \\
\hline \multirow{4}{*}{$\begin{array}{l}\text { Southern Peninsular } \\
\text { Malaysia }\end{array}$} & Urban & Seremban (S13) & $2.43,101.58$ \\
\hline & Urban & Melaka (S14) & $2.15,102.1$ \\
\hline & Suburban & Muar (S15) & $2.03,102,35$ \\
\hline & Urban & Kota Tinggi (S16) & $1.33,104.13$ \\
\hline \multirow[t]{4}{*}{ Malaysian Borneo } & Industrial & Kuching (S17) & $1.33,110.23$ \\
\hline & Suburban & Bintulu (S18) & $3.10,113.02$ \\
\hline & Rural & Miri (S19) & $4.25,114.00$ \\
\hline & Urban & Kota Kinabalu (S20) & $5.53,116.02$ \\
\hline
\end{tabular}

produces two monsoonal seasons, namely the Northeast Monsoon (NEM) (November to February) and the Southwest Monsoon (SWM) (June to August), which greatly influences regional climatic variations (Fig. 1). The two monsoons are separated by two transitional periods, where the wind conditions are generally light and variable. Seasonal monsoons in the region, particularly in the south ASEAN (Malaysia and Indonesia) subregion, have been known to play important roles in the regional air pollutant transport and dispersion. Most notable cases were the significant role of the southwest monsoon to the large scale of transboundary pollution in the region due to biomass burning in Sumatra [38].

In this study, a long period of air quality data (1997-2015) was obtained from 20 air quality monitoring stations across Malaysia from the Department of Environment (DOE). All air quality monitoring stations were equipped with continuous automatic monitoring equipment designed to collect and measure data continuously during the monitoring periods. $\mathrm{CO}$ was measured by Teledyne API Model 300/300E analyser using the non-dispersive, infrared absorption (Beer Lambert) technique. $\mathrm{NO}_{\mathrm{x}}$ was measured by Teledyne API Model 200A/200E analyser using chemiluminescence detection technique. Meanwhile, fully automated continuous monitoring of $\mathrm{PM}_{10}$ was carried out using a $\beta$-ray attenuation mass monitor (BAM1020). The diurnal, seasonal and annual air pollutant concentrations variations were analysed. 
Hourly data were used for the diurnal variations computation, while daily data were used for the seasonal and annual variations.

\subsection{Pollutant temporal dynamic characteristics}

The inter-annual variation characteristics (temporal dynamic) of air pollutants in Malaysia between 1997 and 2015 as based on trend analysis were investigated. The Mann-Kendall (MK) test was employed, as it is capable of detecting a monotonic trend of a time series with no seasonal or other cycles [34,39]. In assessing the extent of inter-annual variability relative to the pollutant mean concentrations over the period of investigation, the variation coefficient, which is the ratio of the standard deviation $(\sigma)$ to the mean $(\mu)$, was also calculated [39].

\subsection{Pollutant Trajectory analyses}

The Hybrid Single-Particle Lagrangian Integrated Trajectory (HYSPLIT) model was used to evaluate the origin and pathway of air mass transport with high value of pollutant concentration. In any given starting location, this model is capable of generating air mass backward trajectories and is thus very helpful in assessing and understanding an air quality event during the selected period. The model was provided by the US National Oceanographic and Atmospheric Administration (NASA), which can be accessed at http://www.arl.noaa.gov/ready. html. The model was developed as a hybrid between the Lagrangian and Eulerian approach, using a moving frame of reference for the advection and diffusion calculations as the trajectories of an air mass from a given location and at the same time computing the air pollutant concentrations using a fixed three-dimensional grid as a frame of reference [40-42]. Despite the HYSPLIT trajectory model's weaknesses, such as the calculated error of up to $30 \%$ (after 24 h) and the non-representation of an air parcel path within the planetary boundary layer (PBL) due to physical processes such as turbulent mixing [41,42], this model is adequate to classify regional-scale air mass motions. To investigate the potential sources of air pollutants from biomass burning, information on regional fire maps was obtained from FIRMS (Fire Information for Resource Management System), which can be accessed at https://firms.modaps. eosdis.nasa.gov/firemap/. The detection of hot spots due to biomass burning in Southeast Asia was based on data acquired by the Moderate Resolution Imaging Spectroradiometer (MODIS) observation instrument on board the NASA's Terra and Aqua EOS satellites, which passes over the region at least four times daily [43].

\section{RESULT AND DISCUSSION}

\subsection{Dynamic variations of $\mathrm{CO}, \mathrm{NO}_{\mathrm{x}}$ and $\mathrm{PM}_{10}$}

Over the period of investigation (1997-2015), monthly concentrations of $\mathrm{CO}, \mathrm{NO}_{\mathrm{x}}$ and $\mathrm{PM}_{10}$ over the northern and central of Malaysian Peninsula showed large variations (Fig. 3). In the northern region, long-term concentrations of $\mathrm{CO}\left(0.96 \mu \mathrm{g} / \mathrm{m}^{3}\right), \mathrm{NO}_{\mathrm{x}}\left(0.051 \mu \mathrm{g} / \mathrm{m}^{3}\right)$ and $\mathrm{PM}_{10}$ $\left(57.75 \mu \mathrm{g} / \mathrm{m}^{3}\right)$ at Perai station were higher than at the other stations. The monthly concentration averages of $\mathrm{CO}$ and $\mathrm{PM}_{10}$ in the northern region showed small spatial pattern but large coefficient variation (Table 2). There were small decreasing trends of $\mathrm{CO}$ and $\mathrm{PM}_{10}$ at a $95 \%$ confidence interval in the northern region. Meanwhile, the monthly $\mathrm{NO}_{\mathrm{x}}$ average concentration varied spatially with a $16.99 \%-34.27 \%$ coefficient variation. The MK test at $95 \%$ 

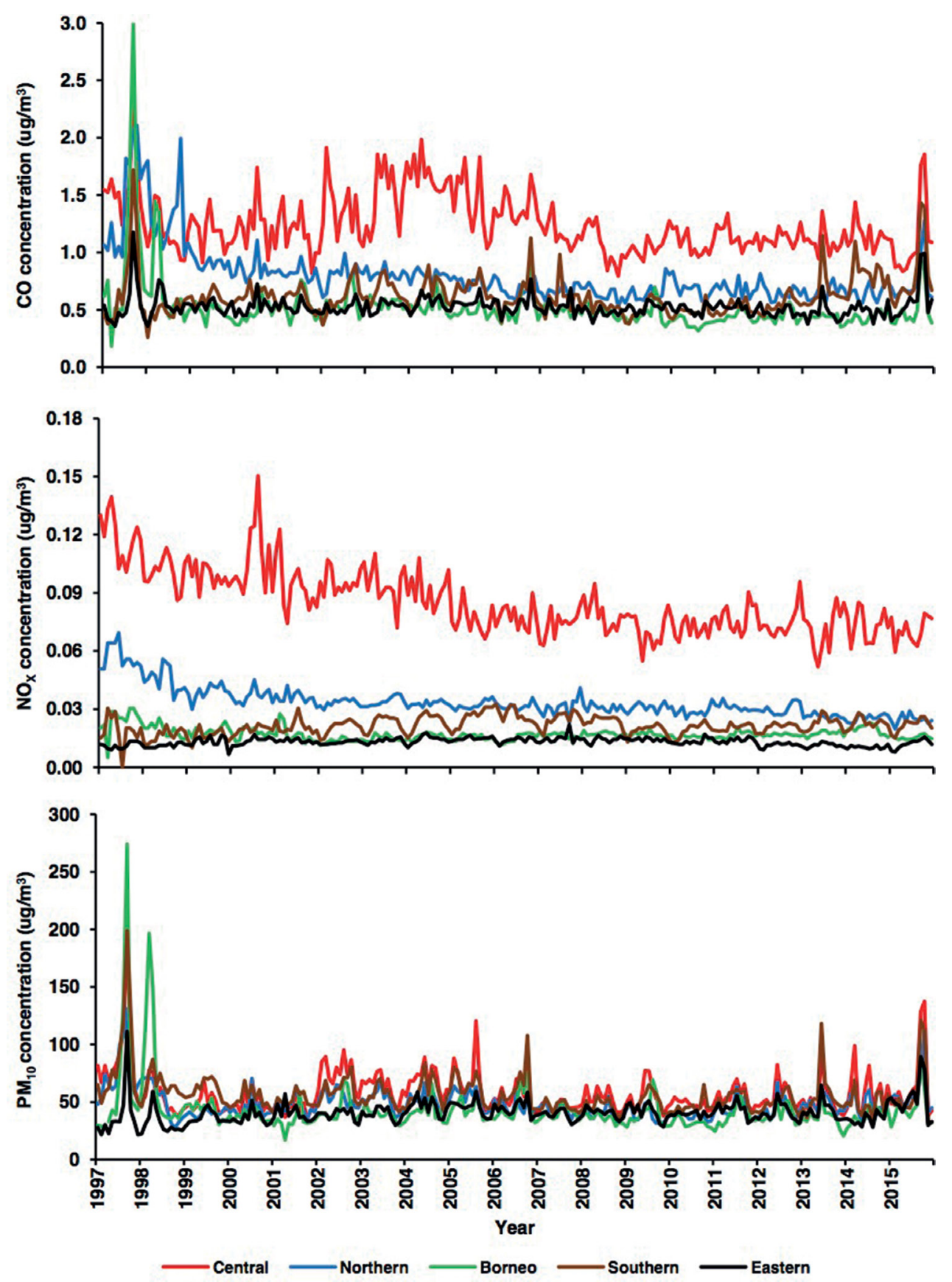

Figure 3: Monthly mean concentrations of $\mathrm{CO}, \mathrm{NO}_{\mathrm{x}}$ and $\mathrm{PM}_{10}$ in each region in Malaysia over the period between 1997 and 2015. 


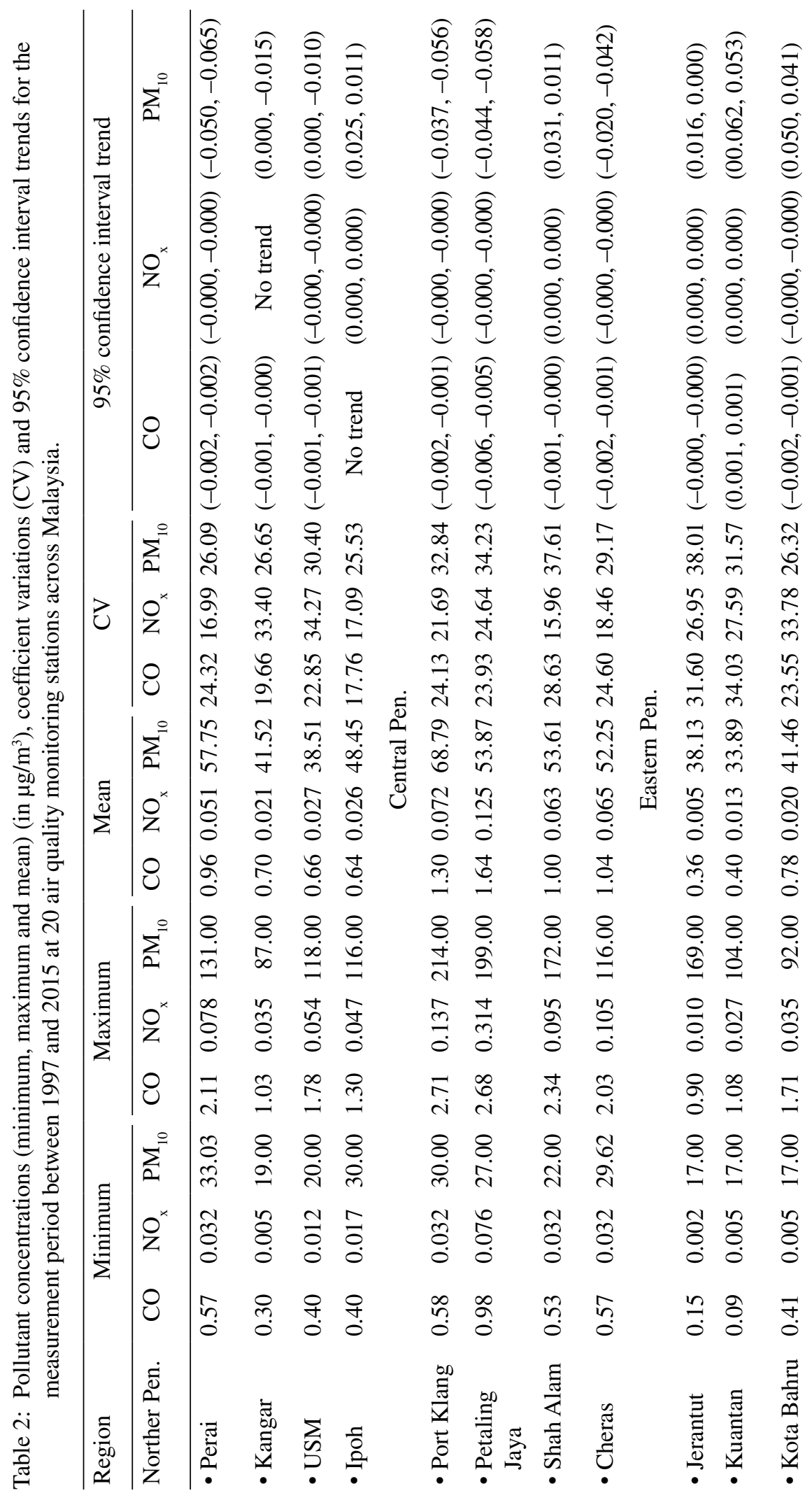




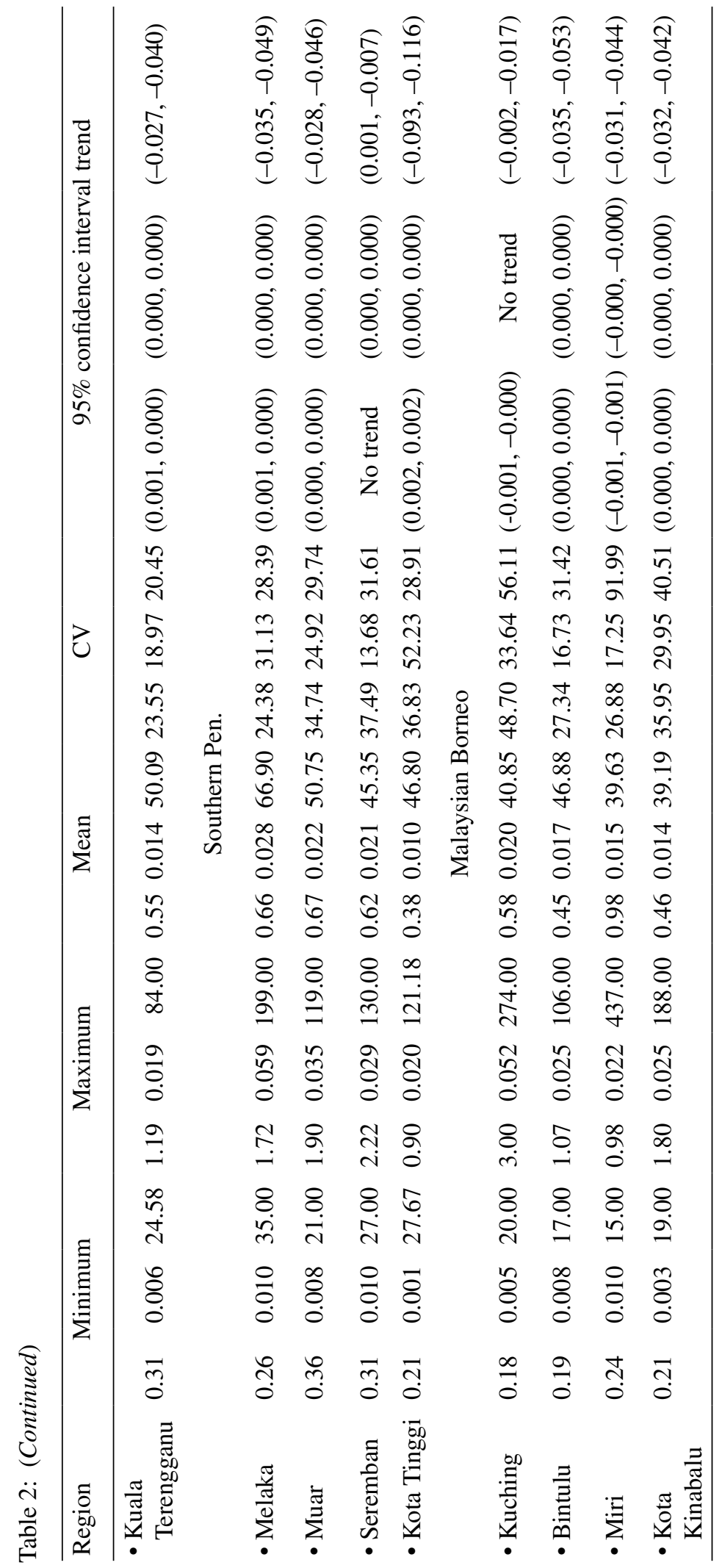


confidence interval trend also showed decreasing trends at Perai and USM stations, a slightly increasing trend at Ipoh station and no trend at Kangar.

The central region had the highest pollutant concentration in Malaysia. The monthly concentration of air pollutants showed small spatial variations except for $\mathrm{PM}_{10}$ (coefficient variation between $29.17 \%$ and $37.61 \%$ ). A small and insignificant trend of $\mathrm{CO}$ and $\mathrm{NO}_{x}$ could be observed in all stations in the central region. However, for $\mathrm{PM}_{10}$, a significant increasing trend was observed in Shah Alam, while other stations showed decreasing trends. Petaling Jaya station was considered a pollutant hots pot for $\mathrm{CO}$ and $\mathrm{NO}_{\mathrm{x}}$ in the country, with the highest average concentrations of $1.64 \mu \mathrm{g} / \mathrm{m}^{3}$ and $0.125 \mu \mathrm{g} / \mathrm{m}^{3}$, respectively. Meanwhile Port Klang had the highest average concentration of $68.79 \mu \mathrm{g} / \mathrm{m}^{3}$, indicating a hot spot area for $\mathrm{PM}_{10}$ pollution.

In southern region, the highest mean concentrations of $\mathrm{CO}, \mathrm{NO}_{\mathrm{x}}$ and $\mathrm{PM}_{10}$ were observed at Melaka station with $0.66 \mu \mathrm{g} / \mathrm{m}^{3}, 0.028 \mu \mathrm{g} / \mathrm{m}^{3}$ and $66.90 \mu \mathrm{g} / \mathrm{m}^{3}$, respectively. The sideway trends of pollutants showed significant spatial variation of pollutants, with large coefficients of variation for $\mathrm{CO}(24.38 \%-37.49 \%), \mathrm{NO}_{\mathrm{x}}\left(13.68 \%-52.23 \%\right.$ and $\mathrm{PM}_{10}(25.39 \%-31.61 \%)$. The southern region showed decreasing trends of $\mathrm{PM}_{10}$ and an insignificant trend of $\mathrm{NO}_{\mathrm{x}}$. Meanwhile, insignificant increasing trends for $\mathrm{CO}$ were observed in all stations in the region except Seremban station, which showed no trend.

On the contrary, the eastern region can be considered the least polluted area, though the monthly mean concentrations of $\mathrm{CO}, \mathrm{NO}_{\mathrm{x}}$ and $\mathrm{PM}_{10}$ showed large variations. Kota Bahru showed the highest average concentrations of $\mathrm{CO}\left(0.78 \mu \mathrm{g} / \mathrm{m}^{3}\right)$ and $\mathrm{NO}_{\mathrm{x}}\left(0.020 \mu \mathrm{g} / \mathrm{m}^{3}\right)$. The pollutant coefficient variations over the eastern region were greatly varied: $\mathrm{CO}(23.55 \%-$ $34.03 \%), \mathrm{NO}_{\mathrm{x}}(18.97 \%-33.78 \%)$ and $\mathrm{PM}_{10}(20.45 \%-38.01 \%)$. The highest mean concentration of $\mathrm{PM}_{10}$ was observed at Kuala Terengganu station with $50.09 \mu \mathrm{g} / \mathrm{m}^{3}$. With the exception of Kuala Terengganu station, the $\mathrm{PM}_{10}$ pollution trends were increasing in all other stations. For other pollutants $\left(\mathrm{CO}\right.$ and $\left.\mathrm{NO}_{\mathrm{x}}\right)$, there were no significant trends observed in all stations.

Over the Malaysian Borneo region, the pollution levels are relatively low in comparison with the Malaysian Peninsula, though the monthly average concentrations of pollutants varied with large coefficient variations from $31.42 \%$ to $91.99 \%\left(\mathrm{PM}_{10}\right), 26.88 \%$ to $48.70 \%$ (CO) and $16.69 \%$ to $33.64 \%\left(\mathrm{NO}_{\mathrm{x}}\right)$, respectively. Significant decreasing trends of $\mathrm{PM}_{10}$ were observed in all stations at $95 \%$ confidence interval trend, though similar trends were not observed for $\mathrm{CO}$ and $\mathrm{NO}_{x}$. In September 1997, this region had the highest concentration of $\mathrm{PM}_{10}\left(436.8 \mu \mathrm{g} / \mathrm{m}^{3}\right)$ ever recorded in Malaysia, primarily due to the intense biomass burning in Indonesian Borneo of Kalimantan as previously described [31,35,38].

\subsection{Associated sources of air pollutants}

Air quality data for the period between 1997 and 2015 were further evaluated to determine the pollutant potential sources and also to assess the roles of the monsoons and the El Niño event. The highest pollutant averages in 1997 and 2015 occurred between September and November. The significant emission of dust particles and gaseous pollutants into the atmosphere is attributed to the large biomass burning in the region and coincidence with the long dry spell in the region due to the El-Niño event. During non-El Niño or weak El Niño events, high pollutant concentrations due to trans-boundary pollution from large biomass burning in Indonesia were also observed over the Malaysian Peninsula in September and October between 2011 and 2014. In such cases, strong winds during the southwest monsoon, which generally occur from June to October, accelerated the pollutant transport towards Peninsular 
Malaysia, thus enhancing the trans-boundary transport and distribution of pollutants over the region [34].

Analysis of the air mass transport by using backward trajectories in October and November 2015 for all regions in Malaysia identified biomass burning in Sumatera, Indonesia, as an associated source of trans-boundary air pollution. During the southwest monsoon, in most cases, the air mass trajectories come from the same direction and sometimes originated from different locations (Fig. 4). From satellite evidence, thick haze in most part of Malaysian Peninsula during this period was caused by the long-range trans-boundary pollution originated from Sumatera, Indonesia. Measurement records of the highest concentration values of $\mathrm{PM}_{10}$ during this period have exceeded the Malaysian Air Quality Guideline Standard $\left(150 \mu \mathrm{g} / \mathrm{m}^{3}\right)$, while in the northern region, Kangar station recorded $338.08 \mu \mathrm{g} / \mathrm{m}^{3}$; central region - Port Klang, $346.43 \mu \mathrm{g} / \mathrm{m}^{3}$; southern region - Seremban, $353.83 \mu \mathrm{g} / \mathrm{m}^{3}$; and eastern region - Kuan$\tan , 275.25 \mu \mathrm{g} / \mathrm{m}^{3}$, respectively. In Malaysian Borneo during this period, $\mathrm{PM}_{10}$ pollution levels in all monitoring stations were not as serious as those in Malaysian Peninsula, but records indicate that the highest $\mathrm{PM}_{10}$ concentration of $436.77 \mu \mathrm{g} / \mathrm{m}^{3}$ was recorded at Miri monitoring station in September 1997. Based on the calculated backward trajectories during this period in Miri station, the air mass transports originated from different locations in Kalimantan Indonesia. The climatic conditions during this period were extremely dry and large hot spots of biomass burning were detected in the southern area of Kalimantan (Fig. 4). These analyses and assessments affirmed that biomass burning and long-range trans-boundary pollution from Indonesia were largely responsible for the seasonally high pollutant concentrations in all regions in Malaysia as previously mentioned in other studies [25,29-37]. In addition to the long-range transport of air pollutants, additional anthropogenic sources such as the emission from motor vehicles and local industrial activities were also associated with high $\mathrm{CO}$ and $\mathrm{NO}_{x}$ especially in urban and industrial areas such as in the central and northern peninsula, as supported by earlier studies at selected monitoring stations $[29,31,44]$.

The occurrence of El Niño phenomenon is common to this region [30,32,34,35,38]. Since 1997, seven El Niño events were recorded, with the strongest intensities in 1997 and 2015 (Fig. 5). Coincident with the occurrence of El Niño events in 1997, 2002, 2009 and 2015, large hot spot areas of biomass burning were detected over south ASEAN (Association of South East Asia Nations), but mostly in Sumatera and Kalimantan. During these events, the persistently high concentrations of $\mathrm{PM}_{10}$ and other primary pollutants such as $\mathrm{CO}$ and $\mathrm{NO}_{\mathrm{x}}$ were notably observed in all regions of Malaysia. These coincident observations were primarily due to long-range trans-boundary pollution from the large and intense biomass burning in Indonesia [30,33]. During the super El Niño events in 1997 and 2015, significantly higher concentrations of $\mathrm{PM}_{10}$ than usual were observed in USM, Shah Alam, Jerantut, Seremban and Kuching in 2015 El Niño and Miri in 1997. Higher concentrations of pollutants during the El Niño events were the amplifying effects of this phenomenon $[35,38,45]$. During El Niño events, the lower atmosphere is extremely dry, coupled with high ambient temperature $[30,31,34,45]$. These conditions lead to severe drought and has become an important accelerator of large-scale biomass burning in the south ASEAN region [30,45].

\section{CONCLUSION}

This study has analysed the long-term trends of air pollution in Malaysia using air quality datasets from 20 monitoring sites across Malaysia, which spanned from 1997 to 2015. For the trend analysis, the monitoring stations were divided into five regions, namely the northern, central, eastern and southern of the Malaysian Peninsula and Malaysian Borneo. Based 

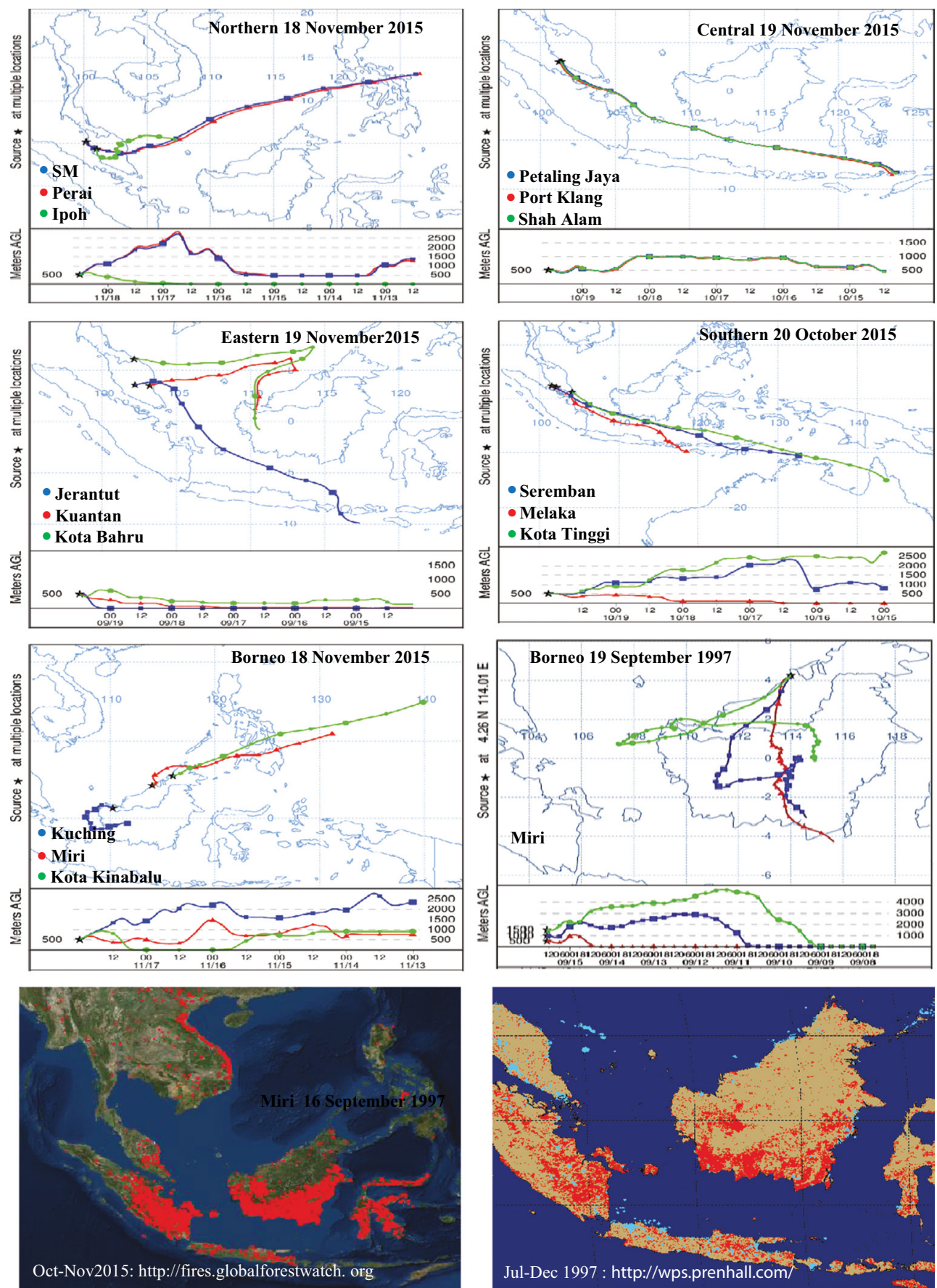

Figure 4: Backward air mass trajectory analysis (first to third panels) and MODIS fire records between October-November 2015 (bottom-left panel) and July-December 1997(bottom-right panel) in Southeast Asia. 

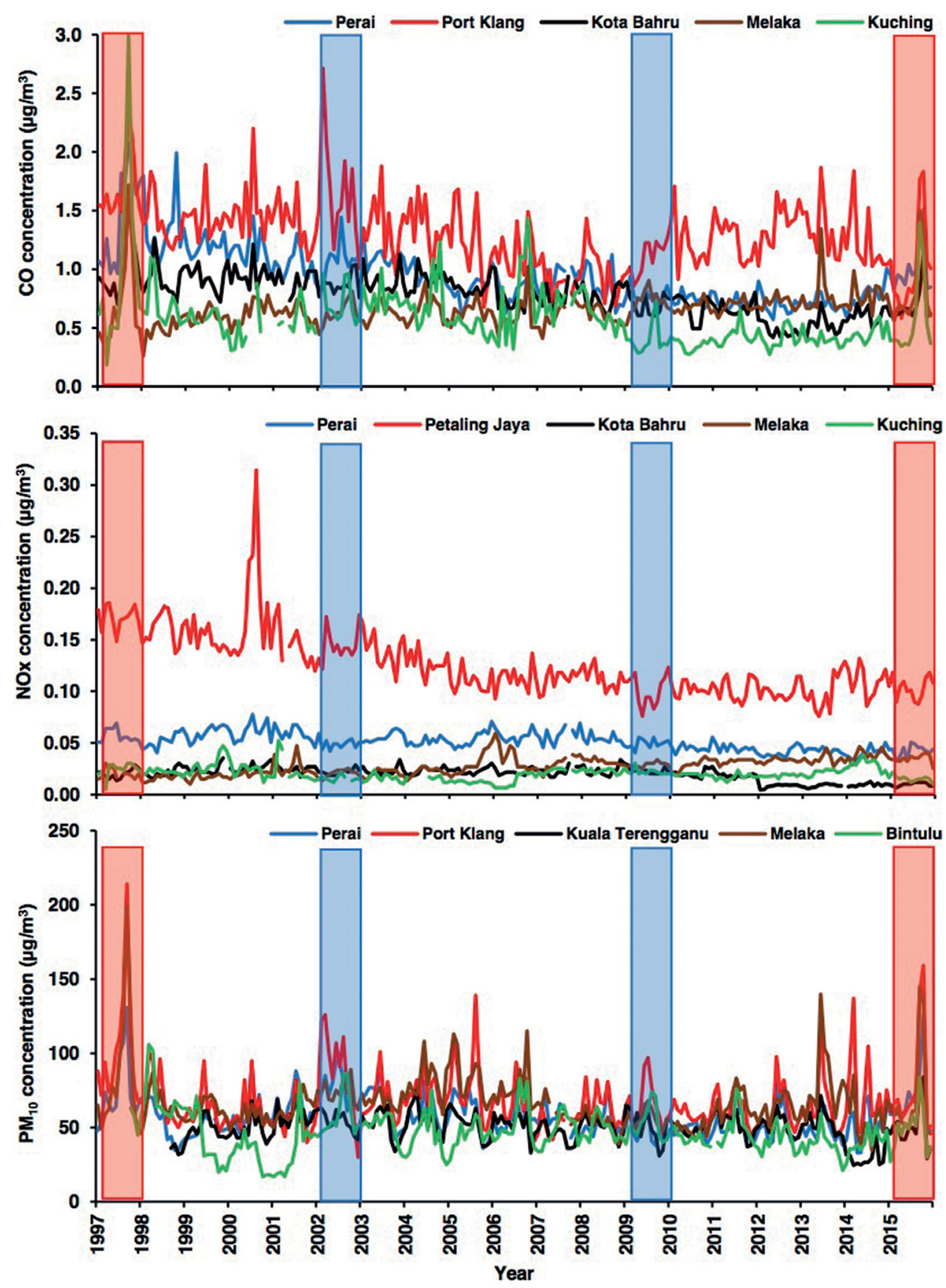

Very-strong El Niño $\square \quad$ Strong El Niño

Figure 5: Time-series analysis for selected monitoring stations (1997-2015) with El Niño events. 
on the long-term measurements, CO pollution in Malaysia has shown small but decreasing trends in the northern and central regions, while the southern region has shown small but increasing trends. Meanwhile, $\mathrm{NO}_{\mathrm{x}}$ pollution has shown increasing trends in the eastern and southern regions but decreasing trend in the central region. For $\mathrm{PM}_{10}$ pollution, all regions have shown mixed trends for the entire period of long-term measurement. The highest level of pollution was observed during the southwest monsoon in September 1997 and between September and October in 2015. Based on HYSPLIT model results, biomass burnings in Kalimantan and Sumatera of Indonesia were found to be the associated sources of pollution in Malaysian Borneo and Peninsular Malaysia regions, respectively. This is to conclude that high level of pollution in Malaysia is spatially and temporally varied, with strong influence of long-range trans-boundary pollution due to the large and intense biomass burning Indonesia. The extremely dry season and warm ambient air temperatures during the El-Niño events in 1997 and 2015 played important roles in accelerating forest fires in the region and delayed the precipitation wash-off of pollutants. Notably, the daily highest $\mathrm{PM}_{10}$ and CO concentrations at all stations in all the five regions were likely linked with the El Niño events, but this is less likely for $\mathrm{NO}_{\mathrm{x}}$. Local anthropogenic sources, especially motor vehicles and industrial activities in the northern and central regions, were likely the associated sources for the relatively higher average concentrations of $\mathrm{CO}$ and $\mathrm{NO}_{\mathrm{x}}$.

\section{ACKNOWLEDGEMENTS}

Datasets for long-term period monitoring on the pollutants CO, NOX and $\mathrm{PM}_{10}$ over Malaysia at 20 monitoring stations were provided by the Department of Environment Malaysia (DOE) and greatly appreciated.

\section{REFERENCES}

[1] Ghorani-Azam, A., Riahi-Zanjani, B. \& Balali-Mood, M., Effects of air pollution on human health and practical measures for prevention in Iran. Journal of Research in Medical Sciences, 21(65), pp. PMC5122104, 2016.

[2] Vallero, D., Fundamentals of Air Pollution, 4th ed, Academic Press: California, USA, 2007.

[3] Robinson, D.L., Air pollution in Australia: Review of costs, sources and potential solutions. Health Promotion Journal of Australia, 16, pp. 213-220, 2005.

[4] Habre, R., Coull, B., Moshier, E., Godbold, J., Grunin, A., Nath, A., Castro, W., Schacter, N., Rohr, A., Kattan, M., Spengler, J. \& Koutrakis, P., Sources of indoor air pollution in New York city residences of asthmatic children. Journal of Exposure Science \& Environmental Epidemiology, 24(3), pp. 269-278, 2014.

[5] David, L.H.F. \& Liptak, B.G., Air Pollution. CRC Press LLC, United States of America, pp. 256, 2000.

[6] Curtis, L., Rea, W., Smith-Willis, P., Fenyves, E. \& Pan, Y., Adverse health effects of outdoor air pollutants. Environment International, 32(6), pp. 815-830, 2006.

[7] Sanidas, E., Papadopoulos, D. P., Grassos, H., Velliou, M., Tsioufis, K., Barbetseas, J. \& Papademetriou, V., Air pollution and arterial hypertension. A new risk factor is in the air. Journal of the American Society of Hypertension, 11, pp. 709-715, 2017.

[8] Baccini, M., Mattei, A., Maelli, F., Bertazzi, P.A. \& Carugno, M., Assessing the short term impact of air pollution on mortality: a matching approach. Environmental Health, 16(7), pp. 1-12, 2017.

[9] Makri, A. \& Stilianakis, N.I., Vulnerability to air pollution health effects. International journal of Hygiene and Environmental Health, 211(3-4), pp. 326-336, 2008. 
[10] Nogueira, J.B., Air pollution and cardiovascular disease. Portuguese Journal of Cardiology, 28(6), pp. 715-733, 2009.

[11] Andersen, Z.J., Kristiansen, L.C., Andersen, K.K., Olsen, T.S., Hvidberg, M., Jensen, S.S., Ketzel, M., Loft, S., Sorenson, M., Tjonneland, A., Overvadm K. \& RaaschouNielsen, O., Stroke and long-term exposure to outdoor air pollution from nitrogen dioxide: A cohort study. Stroke, 43(2), pp. 320-325, 2011.

[12] Snow, S.J., Cheng, W., Wolberg, A.S. \& Carraway, M.S., Air pollution upregulates endothelial cell procoagulant activity via ultrafine particle-induced oxidant signaling and tissue factor expression. Toxicological Sciences, 140(1), pp. 83-93, 2014.

[13] Weisel, C.P., Assessing exposure to air toxics relative to asthma. Environmental Health Prospectives, 110(4), pp. 527-537, 2002.

[14] Stoner, A.M., Anderson, S.E. \& Buckley, T.J., Ambient air toxics and asthma prevalence among a representative sample of US kindergarten-age children, PLOS One, $\mathbf{8}$, pp. e75176, 2013.

[15] Kampa, M. \& Kastanas, E., Human health effects to air pollution. Environment Pollution, 151, pp. 362-367, 2008.

[16] Brunekreef, B., Beelen, R., Hoek, G., Schouten, L., Bausch-Goldbohm, S., Fischer, P., Armstrong, B., Hughesm E., Jerrett, M. \& van den Brantt, P., Effects of long-term exposure to traffic-related air pollution on respiratory and cardiovascular mortality in the Netherlands: the NLCS-AIR study. Research Report Health Effects Institute, 139, pp. 73-89, 2009.

[17] Nakano, T. \& Otsuki, T., Environmental air pollutants and the risk of cancer. Cancer \& Chemotherapy, 40(11), pp. 1441-1445, 2013.

[18] Calderón-Garcidueñas, L., Mora-Tiscareño, A., Ontiveros, E., Gómez-Garza, G., Barragán-Mejía, G., Broadway, J., Chapman, S., Valencia-Salazar, G., Jewells, V., Maronpot, R.R., Henríquez-Roldán, C., Pérez-Guillé, B., Torres-Jardón, R., Herrit, L., Brooks, D., Osnaya-Brizuela, N., Monroy, M.E., González-Maciel, A., Reynoso-Robles, R., Villarreal-Calderon, R., Solt, A.C.\& Engle, R.W., Air pollution, cognitive deficits and brain abnormalities: a pilot study with children and dogs. Brain and Cognition, 68(2), pp. 117-127, 2008.

[19] de Cock, M., Maas, Y.G. \& van de Bor, M., Does perinatal exposure to endocrine disruptors induce autism spectrum and attention deficits hyperactivity disorders? Review, Acta Paediatrica, 101(8), pp. 811-818, 2012.

[20] Van Hee, V.C., Adar, S.D., Szpiro, A.A., Barr, R.G., Bluemke, D.A., Diez Roux, A.V., Gill, E.A., Sheppard, L. \& Kaufman, J.D., Exposure to traffic and left ventricular mass and function: The multi-ethnic study of atherosclerosis. American Journal of Respiratory and Critical Care Medicine, 179(9), pp. 827-834, 2009.

[21] Leary, P.J., Kaufman, J.D., Barr, R.G., Bluemke, D.A., Curl, C.L., Hough, C.L., Lima, J.A., Szpiro, A.A., Van Hee, V.C. \& Kawut, S.M., Traffic-related air pollution and the right ventricle. The multi-ethnic study of atherosclerosis. American Journal of Respiratory and Critical Care Medicine, 189(9), pp. 1093-1100, 2014.

[22] Calderón-Garcidueñas, L., Solt, A.C, Henríquez-Roldán, C., Torres-Jardón, R., Nuse, B., Herritt, L., Villarreal-Calderón, R., Osnaya, N., Stone, I., García, R., Brooks, D.M., González-Maciel, A., Reynoso-Robles, R., Delgado-Chávez, R. \& Reed, W., Longterm air pollution exposure is associated with neuroinflammation, an altered innate immune response, disruption of the blood-brain barrier, ultrafine particulate deposition, and accumulation of amyloid beta-42 and alpha-synuclein in children and young adult. Toxiclogic Pathology, 36(2), pp. 289-310, 2008. 
[23] Haynes, E.N., Chen, A., Ryan, P., Succop, P., Wright, J., \& Dietrich, K.N., Exposure to airborne metals and particulate matter and risk for youth adjudicated for criminal activity. Environmental Research, 118(8), pp. 1243-1248, 2011.

[24] Pope III, C.A., Burnett, R.T., Thun, M.J., Calle, E.E., Krewski, D., Ito, K. \& Thurston, G.D., Lung cancer, cardiopulmonary mortality, and long-term exposure to fine particulate air pollution. Journal of American Medical Association, 287(9), pp. 1132-1141, 2002.

[25] Afroz, R., Hassan, M.N. \& Ibrahim, N.A., Review of air pollution and health impacts in Malaysia. Environmental Research, 92(2), pp. 71-77, 2003.

[26] Wan Mahiyuddin, W.R., Sahani, M., Aripin, R., Latif, M. T., Thach, T.Q. \& C.M., Wong. Short-term effects of daily air pollution on mortality. Atmospheric Environment, 65, pp. 69-79, 2013.

[27] Salahudin, S.N., Abdullah, M.M. \& Newaz, N. A., Emissions: Sources, policies and development in Malaysia. International Journal of Education and Research, 1(7), pp. $1-12,2013$.

[28] Department of Environment (DOE). 2017. Environmental Quality Report 2017. Shah Alam. ISSN 2636-9834, pp 128.

[29] Abudllah, A.M., Abu Samah, M.A. \& Jun. T.Y., An overview of the air pollution trend in Klang Valley, Malaysia. Open Environmental Sciences, 6, pp. 13-19, 2012.

[30] Latif, M.T., Othman, M., Idris, N., Juneng, L., Abdullah, A.M., Hamzah, W.P., Khan, M.F., Nik Sulaiman, N.M., Jewaratnam, J., Aghamohammadi, N., Sahani, M., Xiang, J.C., Ahamad, F., Amil, N., Darus, M., Varkkey, H., Tangang, F \& Jaafar, A.B. Impact of regional haze towards air quality in Malaysia: A review. Atmospheric Environment, 117, pp. 28-44, 2018.

[31] Sahani, M., Zainon, N.A., Wan Mahiyuddin, W.R., Latif, M.T., Hod, R., Khan, M.F., Tahir, N.M. \& Chan, C.C., A case-crossover analysis of forest fire haze events and mortality in Malaysia. Atmospheric Environment, 96, pp. 257-265, 2014.

[32] Ab Manan, N., Hod, R., Sahani, M., Mohd Yusoff, H., Ismail, R. \& Wan Mahiyuddin, W.R., The impact of air pollution and haze on hospital admission for cardiovascular and respiratory diseases. International Journal of Public Health Research, 6(1), pp. 707-712, 2016.

[33] Othman, J., Sahani, M., Mahmud, M. \& Sheikh Ahmad, M.K., Transboundary smoke haze pollution in Malaysia: Inpatient health impacts and economic valuation. Environmental Pollution, 189, pp. 194-201, 2014.

[34] Sentian, J., Jemain, M.A., Gabda, D., Franky, H. \& Wui, J.C.H., Long-term trends and potential associated sources of particulate matter $\left(\mathrm{PM}_{10}\right)$ pollution in Malaysia. WIT Transaction on Ecology and the Environment, 230, pp. 607-618, 2018.

[35] Sulong, N.A., Latif, M.T., Khan, M.F., Amil, N., Ashfold, M.J., Wahab, M.I.A., Chan, K.M. \& Sahani, M., Source apportionment and health risk assessment among specific age groups during haze and non-haze episodes in Kuala Lumpur, Malaysia. Science of the Total Environment, 601-602, pp. 556-570, 2017.

[36] Khan, M.F., Latif, M.T., Saw, W.H., Amil, N., Nadzir, M.S.M., Sahani, M., Tahir, N.M. \& Chung, J.X., Fine particulate matter associated with monsoonal effect and the response of biomass fire hotspots in the tropical environment. Atmospheric Chemistry and Physics Discussion, 15(16), pp. 22215-22261, 2015.

[37] Juneng, L., Latif, M.T. \& Tangang, F., Factors influencing the variation of $\mathrm{PM}_{10}$ aerosol dust in Klang Valley, Malaysia during summer. Atmospheric Environment, 45(26), pp. 4370-4378, 2011. 
[38] Mahmud, M., Assessment of atmospheric impacts of biomass open burning in Kalimantan, Borneo during 2004. Atmospheric Environment, 78, pp. 242-249, 2013.

[39] Shi, Y., Matsunaga, T., Yamaguchi, Y., Li, Z., Gu, X. \& Chen, X., Long-term trends and spatial patterns of satellite-retrieved $\mathrm{PM}_{2.5}$ concentrations in South and Southeast Asia from 1999 to 2014. Science of the Total Environment, 615, pp.177-186

[40] Draxler, R.R. \& Hess, G., An overview of the HYSPLIT_4 modelling system for trajectories. Australian Meteorological Magazine, 47(4), pp. 295-308, 1998.

[41] Stohl, A., Computation, accuracy, and application of trajectories - a review and bibliography. Atmospheric Environment, 32, pp. 947-966, 1998.

[42] Su, L., Yuan, Z., Fung, J.C.H. \& Lau, A.K.H., A comparison of HYSPLIT backward trajectories generated from two GDAS datasets. Science of the Total Environment, 506507, pp. 527-537, 2015.

[43] Giglioa, L., Descloitresa, J., Justicec, C.O. \& Kaufman, Y.J., An enhanced contextual fire detection algorithm for MODIS. Remote Sensing of Environment, 87, pp. 273-282, 2003.

[44] Dominick, D., Juahir, H., Latif, M.T., M Zain, S. \& Aris, A.Z., Spatial assessment of air quality pattern in Malaysia using multivariate analysis. Atmospheric Environment, 60, pp. 172-181, 2012.

[45] Tangang, F., Latif, M.T. \& Juneng, L. The roles of climate variability and climate change on smoke haze occurrences in Southeast Asia region. LSE IDEAS, London. 